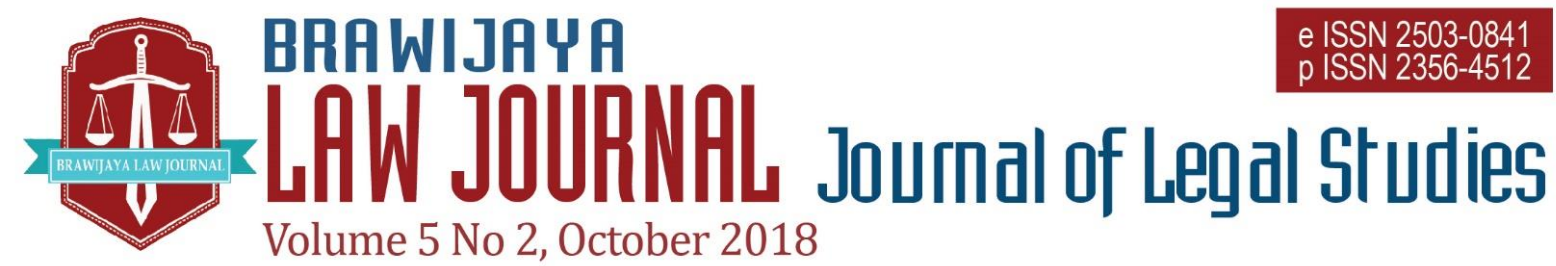

Nationally Accredited No. 32a/E/KPT/2017 Dated 26th April 2017

This work is licensed under a Creative Commons Attribution-NonCommercial 4.0 International License

\title{
State Role in Balancing Harmony in a Diversed Society: Regulating Religions in Indonesia
}

\author{
Iza Rumesten $\mathbf{R S}^{\mathbf{1}}$ \\ ${ }^{1}$ Law Faculty of Sriwijaya University \\ Email: rumesten_iza@yahoo.com
}

Submitted : 2018-05-25 | Accepted : 2018-10-24

\begin{abstract}
As a State in which its society believes in the existence of God, it is not a surprising fact that a number of religions developand recognized in Indonesia. These include Islam, Catholic, Protestan, Hindu, Budha and Konghucu. Since most of Indonesian people are the followers of Islam, this religuions become the majority in Indonesia. Certain matters are regulated separately from the national laws, so that such laws only applicable for muslim. These include arrangement on marriage between moslem, which is provided by Indonesian Act Number 1 Year 1974 on Marriage. Indonesia also has a specific religious court for moslem. The competence of religious court for moslem is clearly stipulated in Article 1 paragraph (1) of Act Number 50 Year 2009 on Religious Courts. Article 49 of the Act stipulates that the religious courts have the duty and authority to examine, decide, and resolve cases in the first instance among Moslim in the field of marriage, inheritance, will, grant, waqaf, zakat, infaq, shadaqah and sari'ah economy.

While some argues that the existance of religious court can be seen as Government failures in guarantee constitutional rights for minority, this paper seeks to find how to prevent potential religious disharmony in Indonesia. Based on the results of normative juridical research, it can be concluded that ideal arrangements related to religion is that it cannot separate the judiciary between Islam and other religions, because it might create possible sense of injustice and disharmony of minority religions. Thus, a specialized religious court for moslem might not be necessary.
\end{abstract}

Keywords: $\quad$ discrimination, arrangement, religion, religious court, Indonesia.

\section{INTRODUCTION}

Before turning into a state, Indonesia has already had diversities among the regions. ${ }^{1}$ According to I Nyoman Nurjaya, ${ }^{2}$ the legal fact of diversity is a legal plurality, where applicable, state law, religious law, and customary law work together and are applied in governance. In addition, the
Iza Rumesten RS, Makna Keragaman Daerah Dalam Pola Hubungan Hukum Antara Pemerintah Pusat dan Daerah pada Negara Kesatuan Republik Indonesia (Disertation, Faculty of Law. Brawijaya University, 2016), 2-3.
2 I Nyoman Nurjaya, Menuntaskan Agenda Reformasi; Dinamika Pembangunan Hukum Di Indonesia, Paper presented at Pengukuhan Guru Besar yang dibukukan, (Malang; Setara Press dan FH UB, 2008), 116. 
presence of $6(\mathrm{six})^{3}$ religions, namely; Islam, Protestantism, Catholicism, Hinduism, Buddhism, Confucianism and other local belief in God The Almighty is embraced by Indonesian people with various growth rates. ${ }^{4}$ The guidance of the six religions is under the Ministry of Religious Affairs, while other beliefs are under the Ministry of Tourism.

The diversity of religion embraced by Indonesian people makes the issue of religion into a very complicated issue and prone to cause conflict. A properly managed diversity will be a strength as it can be a remarkable positive potential for the progress of the nation. On the contrary, diversity can also become a negative strength that can destruct the nation. The founders of the nation have long been aware of it, even before Indonesia independence. This is the proved with the establishment of Bhinneka Tunggal Ika as the motto of Indonesia that means "unity in diversity".

The founders of the country are already aware from the beginning that the issue of religion is very sensitive. Therefore, the formulation of the first principle of Pancasila said "God". This formula reflects the recognition of the equality of all religions. The state then guarantees that everyone is

3 Catalog of Central Bureau of Statistics (BPS), Citizenship, ethnicity, Religion, and the Everyday Language of Indonesia. The Results Of The Population Census Of 2010. Jakarta (Indonesia; Badan Pusat Statistik, 2010), p. 5. See also page http://www.bps.go.id.

http://www.bps.go.id/website/pdf_publikasi/water mark\%20_Kewarganegaraan,\%20Suku\%20Bangs a,\%20Agama\%20dan\%20Bahasa_281211.pdf. Retrieved on September 10, 2015. Regarding the recognition of the sixth of this religion can also be seen on the page http://demografi.bps.go.id/phpfiletree/bahan/kum pulan_tugas_mobilitas_pak_chotib/Kelompok_1/ Referensi/BPS_kewarganegaraan_sukubangsa_ag ama_bahasa_2010.pdf. Retrieved on November 7, 2011 . free to embrace the religion and worship according to each religion. It is expressly 1945 Indonesian Constitution. Furthermore, in Article 29 paragraph (2) of the 1945 Indonesian Constitution, it is clearly stipulated that the state guarantees freedom for each citizen to embrace religion and worship according to their religion and belief.

The formulation of Pancasila first principle and Article 28E paragraph (1) and Article 29 paragraph (2) of 1945 Indonesian Constitution prove that the government respects the right of the religion of the whole Indonesian people as an essential human right. However, there is a denial in terms of religious rule that is set in legislation as follows.

First, the formulation of Article 2, Act Number 3 Year 2006 to Religious Judicature regulates that religious judicature is one of judicial power for Muslim people seeking justice about a particular case. Religious judicature holds law and justice enforcement for the people seeking justice of specific matters for the Muslim community in the field of marriage, inheritance, will, grant, waqaf, zakat, infaq, sadaqah, and Islamic economics. From Article 2, Act Number 3 Year 2006, it is said that those seeking for

4 Based on the population census on 2000 , $88 \%$ of Indonesian people is Islam (Muslim), while the rest are Protestant, Catholic, Hindu and less than $1 \%$ of Indonesia's population is Buddhist, Jewish and traditional religions. http://www.state.gov/g/drl/rls/irf/2009/127271.ht $\mathrm{m}$. Retrieved on November 7, 2017. The results of Indiyanto research based on the management of statistical data on population census on 2000 and 2010 from the Central Bureau of Statistics (BPS) mapping of the growth of religious life in Indonesia as follows. Islam $87 \%$, Christian $7 \%$, Catholic, $2.91 \%$, Hindu To 1.69\%, Buddhist 0.72 Percent, Confucianism Is $0.05 \%$. https://pgi.or.id/membaca-demografi-agamaagama-di-indonesia/ retrieved November 7, 2017. 
justice in Indonesian courts in are both Indonesian citizens and foreigners. The formulation and of explanation Article 2, Act Number 3 Year 2006 has already shown the discrepancy. In the formulation of Article 2, the religious judicature is one of the actors of the judicial power for the people seeking justice who are Muslim about the particular case, while the explanation of Article 2 explains that what is meant by people's seeking justice is every person both Indonesian citizens and foreigners who seek justice in the courts of Indonesia.

Second, Article 1 letter b of Act Number 1 Year 1974 on Marriage. Here, a religious court is for them who are Muslim and district court for non-Muslim. A fundamental question comes from the regulation of this chapter is whether Islam has a higher position than other religions because Muslim community has a special religious court while others religion communities go to the District Court (general court).

Third, Article 49, Act Number 50 Year 2009 in Religious Judicature explains that the Religious Court duty and authority are to examine, decide, and resolve cases at the first level among Muslims in the field of marriage, inheritance, will, grant, waqaf, zakat, infaq, sadaqah and Islamic economics. Those three articles prove the existence of discrimination in the religious rules in Indonesia.

In connection with that matter, Manotar Tampubolon says that Indonesian Government often tolerates the action of extreme groups and fails to enforce the law to protect the minority groups. The government also fails to provide guarantees and fulfillment of the constitutional rights of minority religious

\footnotetext{
5 Manotar Tampubolon, Disfungsi MK Selaku Pengawal Hak-Hak Konstitusional Kelompok Agama Minoritas, in Dri Utari Christina and Ismail Hasani (Ed), Masa Depan Mahkamah Konstitusi
}

groups and often tolerates if any discriminatory action on the minority religions group happens..$^{5}$ This happens due to the presence of discrimination and a discrepancy between the Act Number 50 Year 2009 on Religious Judicial and Act Number 1 Year 1974 on Marriage Article 28E paragraph (1) and Article 29 paragraph (2) of the 1945 Indonesian Constitution. Based on the background, the formulation of the problem discussed in this paper is how to prevent discrimination of regulation of religion in Indonesia.

\section{LEGAL MATERIALS AND METHODS}

This study uses the normative method. The approach used in article writing is the legislation approach and analytical approach. The law analyzed in this study includee international laws, which are Universal Declaration of Human Rights 1948 and International Covenant on Civil and Political Rights. Whereas nationall laws include Indonesian Act Number 1 Year 1974 on Marriage, Act Number 50 Year 2009 on Religious Court, Act Number 3 Year 2006 on Religious Judicature, Act Number 48 Year 2009 on Judicial Power as well as the 1945 Indonesian Constitution. The legal materials used in this research were primary and secondary laws. Primary legal materials are in the form of laws and court decisions. Secondary legal materials are in the form of legal books, law papers and journals.

\section{RESULTS AND DISCUSSIONS \\ a. Religion and Human Rights}

UN (United Nations) states that religion is a personal attribute equal to race, ethnicity, and gender. It is seen as a natural

RI (Naskah Konferensi Mahkamah konstitusi Dan Pemajuan Hak Konstitusional Warga) (Jakarta: Pustaka Masyarakat Setara, 2013), 164. 
phenolmenon that can lead to a discrimination as it recognizes religion as right and freedom. ${ }^{6}$ The definition of religion, according to the High Court of Australia is a complex of beliefs and practices which point to a set of values and an understanding of the meaning of existence. ${ }^{7}$

Another definition of religion is based on the decision of the United States Supreme Court between Davis VS. Beason, 133.U.S., 333, 342, 10 S.Ct 229, 33 L. ED.637 (1890). ${ }^{8}$ It states that religion is: whether a given that is sincere and meaningful occupies a place in the life of its possessor parallel to that filled by the orthodox belief in God of one who clearly qualifies for the exemption. Where such beliefs have parallel positions in the lives of their respective holders we cannot say at one is in relation to the Supreme Being and the other is not.

Freedom of religion is a fundamental right included in 16 rights that cannot be reduced in any circumstances (not - derogable right). ${ }^{9}$ The right of religion cannot be taken by anyone (unalienable) because it is determined by the person itself and without coercion and not imposed by others. ${ }^{10}$ Therefore, in the practices, the state cannot intervene in the citizen's freedom of religion, and the state is obliged to give The guarantee to the citizen to worship without any interference. The state should also guarantee that there is no discrimination on the person

6 Brice Dickson, 'The United and the Freedom of Religion, the International and Comparative Law', (1995) 442 Cambridge University Press on behalf of the British Institute of International and Comparative Law Stable, Quarterly, 327-357.

7 Rebbeca Wilson and Mary R Power, Conflict Resolution Styles Among Australian Christian and Moslem, (Bond University: Humanity and Social Science Papers, 2004), 60.

8 Frank S. Ravitch, Law and Religion A. Reader: Cases, Concept, and Theory, the American Case Book Series, (Second Edition, 2008), 580. or group of people that are committed in the name of religion. ${ }^{11}$

Indonesia, despite being the world's most populous Muslim-majority country, has since independence pursued a non-setarian state and a non-sectarian national identity. ${ }^{12}$ Although the majority population of Indonesia is Muslim Indonesia is not a religious state, as a religious state only based on one particular religion that is clearly regulated in the constitution. There is no paragraph in the 1945 Indonesian Constitution, which states that Indonesia is a religious state or Islam is the only official religion of the state. However, Indonesia is not a secular state because a secular state does not involve in the religion affairs embraced by the people at all, and hands over the issue of religion on the individual.

Indonesia is based on Pancasila, so Indonesia cannot be called as a secular state. A state based on Pancasila is a religious nation protecting and facilitating the development of all religions embraced by the people without exception, so that the state has a constitutional obligation/judicial review to protect the freedom of religion for every citizen.

With regard to human rights, the Constitutional Court argues that freedom of religion is not a value-free freedom and freedom solely but rather a freedom that is accompanied by the social responsibility to realize human rights for everyone

9 Paris Minimum Standards of 1984.

10 Michael W. McConnel, John H. Garvey and Thomas C. Berg, Religion and the Constitution, 2nd Edition,( New York: Aspen Publishers, 2006), 49.

11 Article 4 paragraph (1) of the Declaration on the elimination of all forms of intolerance and of discrimination based on religion or belief 1981 .

12 Kevin W. Fogg, 'Islam in Indonesia's Foreign Policy 1945-1949' (2015) 532 Al-Jami'ah Journal of Islamic Studies 303-335. 
(Par.3.34.18). In relation to such freedom of religion, then the state has a role as a counterweight between basic right and obligation to ensure that in the imple-mentation of a person's freedom of religion does not injure the freedom of other religions. So, the state will realize the goal to achieve a better life (the best life as possible). ${ }^{13}$

The right and freedom of religion (freedom of belief) are one of the funda-mental rights written in the Universal Declaration of Human Rights (UDHR) 1948, as the highest aspiration of the common people, in addition to the freedom of speech, freedom from fear, freedom from want. This shows that the freedom of religion is the most fundamental right in the life of the world community.

The right and freedom of religion later is mentioned in the provision of Article 18 of the UDHR that states: Everyone has the right to freedom of thought, conscience, and religion; this right includes freedom to change his religion or belief, and freedom, either alone or in community with others and in public or private, to manifest his religion or belief in teaching, practice, worship, and observance.

Freedom of religion is also regulated in Article 18 of the International Covenant on Civil and Political Rights (ICCPR): Everyone shall the right to freedom of thought, conscience, and religion. This right shall include freedom to have or to adopt a religion or belief of his choice, and freedom, either individually or in community with others and in public or private, to manifest his religion or belief in worship, observance, practice, and teaching.

Article 18 of UDHR and ICCPR implies that everyone has the right to

13 Putusan Mahkamah konstitusi No. 140/PUUVii/2009, Par. 6.2:321-322.

14 Javier Martinez-Torron, 'The (UN) Protection of Individual Religious Identity in the Strasbourg freedom of religion including 1 . Freedom for each person to hold or accept a religion or belief of his/her choice, as well as change the religion and belief chosen. This is an internal freedom or called as forum internum ${ }^{14}$. Article 18 paragraph (2) of the ICCPR mentions that no one shall be subject to coercion, which would impair his freedom to have or to adopt a religion or belief of his choice. It means that in the forum internum there should not be any coercion in any form that may damage or interfere with the freedom to have or adopt the religion and belief chosen. 2. Freedom to manifest religion or belief in teaching, practice, worship and obey it, either alone or with others and in public or alone. This freedom is external freedom or called as forum externum. ${ }^{15}$ Article 18 paragraph (3) of the ICCPR mentions that the freedom to manifest one's religion or belief may be subject only to such limitations as are prescribed by law and are necessary to protect public safety, order, health, or morals or the fundamental rights and freedom of others. It means that the restrictions can be carried out in connection with the forum externum based on law (legislation) on the basis of consideration of the interests of public safety, order, health or morals or the right and freedom of other people.

Therefore, forum internum relates to freedom to embrace belief, faith or aqidah that cannot be interfered by anyone, while the forum externum is about freedom to implement the religion or worship in which the implementation shall be regulated by the state based on the consideration of public safety protection, order, health, moral or right

Case Law', (2012) 12 the Oxford Journal of Law and Religion, 4.

15 Ibid. 
and freedom of other people. ${ }^{16}$ Taylor ${ }^{17}$ said that forum internum is a personal area of an internal person rights where the state could not interfere in these rights in any occasion.

Refer to general comment number 22 of United Nation on Human Rights Committee (HRC) Article 18 (Forty-eighth session, 1993), par. 2, it is mentioned that the provisions of Article 18 of ICCPR include the protection of: Theistic, non-theistic and atheistic beliefs, as well as the right not to profess any religion or belief. The terms "belief" and "religion" are to be broadly construed. Article 18 is not limited in its application to traditional religions or to religions and beliefs with institutional characteristics or practices analogous to those of traditional religions. The Committee therefore views with concern any tendency to discriminate again any religion or belief for any reason, including the fact that they are newly established, or representation on the part of a predominant religious community.

Therefore, the term "religion" and "belief" include a broad understanding and not just limited to theistic, non-theistic and atheistic beliefs such as animism, dynamism, or paganism, and atheist. The right not to embrace the religion or belief is not only about traditional religion and belief, but also the newly established religion or belief or represent minority's religious that may be the subject of hostility from the believers of the dominant religion.

The protection of right of worship in Indonesia is regulated in Article 28E para-

16 Aidul Fitriciada Azhari, Partikulasi Dalam Putusan MK RI Tentang Kebebsan Beragama in Dri Utari Christina dan Ismail Hasani (Ed) Masa Depan Mahkamah Konstitusi RI (Naskah Konferensi Mahkamah Konstitusi dan Pemajuan Hak Konstitusional Warga) (Jakarta: Pustaka Masyarakat Setara, 2013), 98.

17 Taylor Paul M, Freedom of Religion, UN and European Human Rights Law and Practice, graph (1 and 2) of the 1945 Indonesian Constitution, which regulates that (1) everyone is free to embrace the religion and worship according to his/her religion, choose education and teaching, choose a job, choose citizenship, choose residence in the territory of the state and leave it, and return. (2) Every person is entitled to the freedom to embrace a belief, stating what is in mind and act in accordance with his/her conscience.

Then, this article is emphasized again in Article 29 paragraph (2) of the 1945 Indonesian Constitution, which stipulates that the state guarantees freedom of each citizen to embrace the religion and to worship according to the religion and belief. Article 28E paragraph (1) and Article 29 paragraph (2) show a genuine commitment from the Indonesian Government to protect the right of Indonesian people in terms of religion. However, this does not guarantee that the regulation and implementation of religion matter in Indonesia have been going well.

The annual report of the international commission on freedom of religion was issued by the US. Commission on International Religious Freedom of 2013. The commission, in its report, stated: ${ }^{18}$ Indonesia is a stable and robust democracy with political institutions able to advance and protect human rights. In recent years, however, the country's tradition of religious tolerance and pluralism have been strained by ongoing sectarian tensions, societal violence, and the arrest of individuals considered religiously "deviant". While the government

(Cambridge: Cambridge University Press, 2005), 115.

18 Annual Report of the United State Commission on International Religious Freedom for 2013, United State Department of state, http://www.uscirf.gov/images/2013\%20USCIRF $\% 20$ Annual\%20\%282\%29.pdf. Accessed 27 Desember 2017. 
has addressed past sectarian violence and effectively curtailed terrorist networks, religious minorities continue to experience intimidation, discrimination, and violence. The Indonesian government, including the local police, provincial officials and, the courts, often tolerate the activities of extremist groups, fails to enforce national laws protecting religious minorities, and issues lenient sentences to individuals arrested for engaging in violence. In addition, national laws and provincial decrees have led to serious abuse of the freedom of thought, conscience, and religion or belief, including destruction or forced closure of religious venues and imprisonment of individuals accused of blasphemy or "deviant" "religious teachings".

Based on the report of the commission, Indonesian Government often tolerates the action of extreme groups and fails to enforce the law to protect the minority groups. The government also fails to provide guarantees and fulfillment of the constitutional rights of minority religious groups and often tolerates if any discriminatory action on the minority religion group happens. ${ }^{19}$

\section{b. Regulation of Religion in Laws and Legislation}

Human Rights as one of the material content of constitutionally indicates two meanings of protection guaranteed by the constitution itself. First, in ruling the state, the authority is restricted by the rights of a citizen. Second, there is a guarantee of strong protection in the state basic law (constitution), so that the citizens can make the constitution as an instrument to remind the authority to not violate Human Rights

19 Brice Diskson, above n. 6, 164.

20 Sri Hastuti PS, 'Perlindungan HAM Dalam Empat Konstitusi di Indonesia', (2005) 11 Jurnal Magister Hukum, 11-12. that have been listed in the constitution in exercising the power. ${ }^{20}$

Mahfud MD said that in the violation of Human Rights, it does not only performed blatantly by violating the law, but it also performed legally through the formality procedure because the Legislature on violation of Human Rights has been made first to justify it. ${ }^{21}$ This is what happens with the enactment of Act Number 50 Year 2009 on Religious Judicature, Article 1 paragraph (1) that clearly stipulates that religious judicature is a justice for the Muslim. Furthermore, in Article 49, it stipulates that the religious court has a duty and authority to examine, decide, and resolve matters at the first level among Muslims in the field of marriage, inheritance, will, grant, waqaf, zakat, infaq, sadaqah and Islamic economics. The Article 1 letter $b$ of Act Number 1 Year 1974 on Marriage also related. That firmly set that what is meant by the court is a Religious Court for them who are Muslim and District Court for others.

Therefore, it proves that the government has discriminated the regulation of the religion of all Indonesian people in a structured and assertive manner. Indeed, it proves that the government fails to provide security to the believer of the minority religion to worship, including formulating a discriminatory policy as well as the politicization of religion for certain interests. The fact it has been regulated firmly that the right of religion is a fundamental right and things that are associated with the implementation of religious activities is the duty of government to ensure the implementation. 21 Mahfud MD., Politik Hukum di Indonesia (Jakarta:
LP3ES, 1998), 158. 
The protection of fundamental rights becomes important to be underlined in any state of law (democracy) that put the constitution as the supreme law in the state concerned. When the fundamental rights are included in the constitution, it becomes the part of the constitution, and then it binds all branches of state authorities. $^{22}$

The letter a of Act Number 48 Year 2009 on Judicial Power clearly regulates that the judicial power, according to the 1945 Indonesian Constitution is an independent power performed by a Supreme Court and judicial institutions under it in the general court, religious court, military court, state administrative court, and Constitutional Court organize the judiciary to enforce law and justice.

The contents of the article clearly refer to religious judicature. So, it should cover and protect all religions embraced by Indonesian people, without seeing the majority or minority. It is important so that any discrimination regarding religious court that is only for Muslim will not happen.

It can be seen from the first, Act Number 50 Year 2009 on the Religious Judicature in Article 1 paragraph (1), which explicitly regulates that religious court is only for Muslims. Second, Article 1 letter b of Act Number 1 Year 1974 on Marriage, explains that the religious court only for them who are Muslim and District Court for the others. Third, Article 2 of Government Regulation Number 9 Year 1975 on Implementation of Act Number 1 Year 1974 on Marriage, the Marriage Registration Office is for those who hold marriage based on Islam and Population and Civil

22 Duga Das Basu, Human Right in Constitutional Law (New Delhi-Nagpur-Agra: Wadhwa and Company, 2003), 107.

23 Aidul Fitriciada Azhari, 'The Essential of the 1onstitution and the Agreement of the 1945 Constitution: A Comparison of the Constitutional
Registration Agency is for non-Muslims who hold marriage. Fourth, divorce can only be done through the court (Article 39 of Act Number 1 of 1974). Fifth, Marriage for Indonesian Citizens (WNI) who are not Muslim is subject to article 2 of Act Number 1 Year 1974.

Those regulations are contradictive with: 1) Article 27 paragraph (1) of the 1945 Indonesian Constitution regulating that all of the citizens of the state are equal before the law and government, is obliged to uphold the law and government with no exception. 2) Article 28E paragraph (1) of the 1945 Indonesian Constitution regulates that everyone free to embrace religion and worship based on the religion. 3) Article 29 paragraph (2) of the 1945 Indonesian Constitution clearly regulates that the state guarantees the freedom of each person to embrace the religion and to worship based on the religion and belief. Article 29 of the 1945 Indonesian Constitution, according to Aidul $^{23}$ is viewed by the state founders as the essence of the 1945 Indonesian Constitution that shall not be amended even if 1945 Indonesian Constitution is amended.

\section{c. Efforts to Prevent Discrimination on Regulation of Religion}

The supremacy of the constitution requires consistency and harmonization in the formation and preparation of legislation and state policies by putting the 1945 Indonesian Constitution as the supreme law. Maruar Siahaan ${ }^{24}$ said that these include institutional forms assigned to enforce the principle of constitution supremacy and how the mechanisms of it.

Amendment', (2016) 183 Jurnal Hukum Ius Quia Iustum, 306.

24 Maruar Siahaan, 'Uji Konstitusionalitas Peraturan Perundang-Undangan Negara Kita; Masalah dan Tantangan', (2010) 74 Jurnal Konstitusi, 10. 
Dwiyana $^{25}$ said that in the perspective of the rule of law in Indonesia, the functions of state shall protect each religion and the believer by ensuring the implementation of worship, providing support facilities and maintaining inter-religious harmony, including laws and regulations both private and public.

Hans Kelsen ${ }^{26}$ introduced the theory of legal norm hierarchy (Stufentheorie), where the norms of law are tiered and layered in a hierarchy, while the lower norm is applicable, sourced and based on the higher norms. When the higher norm is applicable, it is sourced and based on the much higher norm, and so on until the highest norm called as the fundamental norm (Groundnorm).

Based on this theory, the regulations in Article 1 letter b of Act Number 1 Year 1974 on Marriage, Article 1, paragraph (1) and Article 49 of the Act Number 50 Year 2009 on Religious Judicature should not be contrary to Article 27 paragraph (1), Article 28E paragraph (1) and Article 29 paragraph (2) of the 1945 Indonesian Constitution. The discriminatory regulation in law can be categorized as a human rights violation, a failure to provide the rights of communities apart from the Muslims to obtain the same treatment. In connection with that matter, Donelly $^{27}$ said that the violation of the individual rights is not only limited to the violation of the law for the victims, but also a failure in providing their rights and enforcing the rights that are deemed to be legally correct.

The regulation in Article 1 letter $b$ of Act Number 1 Year 1974 on Marriage,

25 Dwiyana Achmad Hartanto, 'Kontribusi Hukum Islam Dalam Pembaharuan Hukum Pidanan Di Indonesia (Studi Pidana Cambuk di Nanggroe Aceh Darussalam)', (2016) 12 Jurnal Al-Ahkam, 1.

26 Hans Kelsen, General Theory of Law and State, (New York: Russell \& Russell, 1945), 112-113.
Article 1 paragraph (1) and Article 49 of Act Number 50 Year 2009 on Religious Judicature prove that the government fails to provide equal rights for other citizens other than Muslims. The government only makes the Religious Court as a judicial institution for Muslims. The religious court should be applied to all Indonesian citizens without distinction of religion. There should be any room/section for each religion in Religious Court.

One religious judicature institution that has six rooms or section where each religion has one place, will eliminate the discriminatory regulation to the Indonesia that has six official religions. This can be performed by amending the contents of Article 1 part $b$ of Act Number 1 Year 1974 on Marriage, Article 1 paragraph (1) and Article 49 of Act Number 50 Year 2009 on Religious Judicature, without having to amend the 1945 Indonesian Constitution.

\section{CONCLUSIONS AND SUGGESTIONS}

The 1945 Indonesian Constitution has already stated that all citizens are equal before the law and government and must uphold the law and government with no exception. This ideal regulation should be followed by the Act Number 1 Year 1974 on Marriage and Act Number 50 Year 2009 on the Religious Judicature with no specialized religious courts that is only for Muslims.

Ideally, a religious judicature covers the six official religions recognized by the state, by making a room or section for each religion. Therefore, the regulation will eliminate the discriminatory settings for an-

27 Donelly Jack, 'Human Rights and Human Dignity: an Analysis Critique of Non-Western Conceptions of Human rights', (1982) 762 The American Political Science Review, 304. 
Muslim citizens and can be implemented without having to amend the 1945 Indonesian Constitution, because Article 27 paragraph (1), Article 28E paragraph (1) and Article 29 paragraph (2) of the 1945 Indonesian Constitution have already regulated the citizen rights in terms of religion ideally.

\section{REFERENCES}

\section{Books}

Azhari, Aidul Fitriciada, Partikulasi Dalam Putusan MK RI Tentang Kebebsan Beragama, Dalam Buku: Masa Depan Mahkamah Konstitusi RI (Naskah Konferensi Mahkamah Konstitusi Dan Pemajuan Hak Konstitusional Warga), Ed. Dri Utari Christina dan Ismail Hasani, Jakarta: Pustaka Masyarakat setara, 2013.

Basu, Duga Das, Human Right in Constitutional Law, New DelhiNagpur-Agra: Wadhwa and Company, 2003.

McConnel, Michael W., John H. Garvey and Thomas C. Berg, Religion and the Constitution, 2 nd Edition, New York: Aspen Publisher, 2006.

Nurjaya, I Nyoman, Menuntaskan Agenda

Reformasi; Dinamika Pembangunan

Hukum Di Indonesia, Paper presented at Pengukuhan Guru Besar yang Dibukukan, Malang; Setara Press Dan FH UB, 2008.

Katalog BPS, Kewarganegaraan, Suku Bangsa, Agama, dan Bahasa seharihari Penduduk Indonesia. Hasil Sensus Penduduk Tahun 2010, Jakarta; Badan Pusat Stastik, 2010.

Kelsen, Hans, General Theory of Law and State, New York: Russle \& Russell, 1945.

MD, Mahfud, Politik Hukum Di Indonesia, Jakarta: LP3ES, 1998.
Paul, Taylor M., Freedom of Religion, UN and European Human Rights Law and Practice, Cambridge: University Press, 2005.

Ravitch, Frank S., Law and Religion A. Reader: Cases, Concept and Theory, American Case Book Series, Second Edition, 2008.

Tampubolon, Manotar, Disfungsi MK Selaku Pengawal Hak-Hak Konstitusional Kelompok Agama Minoritas, Dalam Buku: Masa Depan Mahkamah Konstitusi RI (Naskah Konferensi Mahkamah Konstitusi Dan Pemajuan Hak Konstitusional Warga), Ed. Dri Utari Christina dan Ismail Hasani, Jakarta: Pustaka Masyarakat setara, 2013.

Wilson, Rebbeca and Marry R Power, Conflict Resolution Styles Among Australian Chiristian and Moslem, Bond University: Humanity and Social Science Papers, 2004.

\section{Journal Articles}

Azhari, Aidul Fitriciada 'The Essential of the 1onstitution and the Agreement of the 1945 Constitution: A Comparison of the Constitutional Amendment', (2011) 183 Jurnal Hukum 305-319

Dickson, Brice, 'The United and Freedom of Religion', (1995) 442 the International and Comparative Law Quarterly, 327-357.

Hartanto, Dwiyana Achmad, 'Kontribusi Hukum Islam Dalam Pembaharuan Hukum Pidana Di Indonesia (Studi Pidana Cambuk Di Nanggroe Aceh Darussalam)', (2016) 12 Jurnal AlAhkam, 171-192

Jack, Donelly, 'Human Rights and human Dignity: an Analysis, Critique of NonWestern Conceptions of Human 
rights', (1982) 762 The American

political Science Review, 312-13.

Fogg, Kevin W. 'Islam in Indonesia's Foreign Policy 1945-1949’, (2015) 532 Al-Jami'ah Journal of Islamic Studies, 303-335

Martinez Torron, Javier 'The (UN) Protection of Individual Religious Identity in the Strasbourg Case Law', (2012) Oxford Journal of Law and Religion, 363-385

PS, Sri Hastuti, 'Perlindungan HAM Dalam Empat Konstitusi Di Indonesia’, (2005) 11 Jurnal Magister Hukum

Siahaan, Maruar, 'Uji Konstitusionalitas Peraturan Perundang-Undangan Negara Kita; Masalah Dan Tantangan', (2010) 74 Jurnal Konstitusi, 009-048.

\section{Thesis/ Disertation}

RS, Iza Rumesten, Makna Keragaman Daerah Dalam Pola Hubungan Hukum antara Pemerintah Pusat dan Daerah pada Negara Kesatuan Republik Indonesia, Disertasi, Fakultas Hukum Universitas Brawijaya, 2016.

\section{Internet:}

http://www.uscirf.gov/images/2013\%20US CIRF\%20Annual\%20\%282\%29.pdf. Annual Report of the United State Commission on International Religious Freedom for 2013, United State department of state.

http://www.bps.go.id.

http://www.bps.go.id/website/pdf_publikasi/ watermark\%20_Kewarganegaraan,\%2 0Suku\%20Bangsa,\%20Agama\%20dan \%20Bahasa_281211.pdf. Retrieved 10 September 2015.

http://demografi.bps.go.id/phpfiletree/bahan /kumpulan_tugas_mobilitas_pak_choti b/Kelompok_1/Referensi/BPS_kewarg anegaraan_sukubangsa_agama_bahasa _2010.pdf. Accessed 7 November 2011.

http://www.state.gov/g/drl/rls/irf/2009/1272 71.htm. Accessed 7 November 2017. https://pgi.or.id/membaca-demografi agama-agama-di-indonesia/. Retrieved 7 November 2017.

\section{Legislation}

Putusan MK No. 140/PUU-Vii/2009.

Undang-Undang No. 1 Tahun 1974 tentang Perkawinan. Lembaran Negara Republik Indonesia Tahun 1974 No. 1. Tambahan Lembaran Negara No. 3019 Undang-Undang No. 3 Tahun 2006 tentang Perubahan Atas Undang-Undang No. 7 Tahun 1989 tentang Peradilan Agama. Lembaran Negara Republik Indonesia Tahun 2006 No. 22. Tambahan Lembaran Negara Repu-blik Indonesia No. 4611

Undang-Undang No. 39 Tahun 1999 tentang Hak Asasi Manusia. Lembaran Negara No. 165, Tambahan Lembar-an Negara No. 3886

Undang-Undang No. 50 Tahun 2009 tentang Peradilan Agama merupakan perubahan ke tiga atas Undang-Undang No. 7 Tahun 1989 tentang Peradilan Agama sebagaiman telah diubah de-ngan Undang-Undang No. Undang-Undang No. 3 Tahun 2006 tentang Perubahan Atas Undang-Undang No. 7 Tahun 1989 tentang Peradilan Agama

Undang-Undang No. 48 tahun 2009 tentang kekuasaan kehakiman Lembaran Negara Republik Indonesia Tahun 2009 No. 157. Tambahan Lembaran Negara Republik Indonesia No. 5076 